\title{
MARKET OUTLET CHOICE DECISION AND ITS EFFECT ON INCOME AND PRODUCTIVITY OF SMALLHOLDER VEGETABLE PRODUCERS IN LAKE TANA BASIN, ETHIOPIA
}

\author{
Marelign ADUGNA $^{* 1}$ (D) , Mengistu KETEMA ${ }^{1}$ (D), Degye GOSHU ${ }^{2}$ (D), Sisay DEBEBE ${ }^{3}$
}

\author{
Address: \\ ${ }^{1}$ School of Agricultural Economics and Agribusiness Management, Haramaya University, Ethiopia \\ ${ }^{2}$ Department of Economics, Kotebe Metropolitan University, Addis Ababa, Ethiopia \\ ${ }^{3}$ Department of Rural Development and Agricultural Extension, Arba Minch University, Ethiopia \\ * Corresponding author: marlynk3@gmail.com
}

\begin{abstract}
One of the challenges of perishable vegetable production is selecting appropriate market outlets to deliver the produce fresh and earn better price. Various factors affect producers' decision to choose among the alternative market outlets. This study was aimed to identify determinants of smallholder vegetable producers' decision on market outlet choice and verify the existence of difference in productivity and income of households among different market outlets in Lake Tana basin, Ethiopia. Using primary data collected from a survey of 385 farmers in three districts located in Lake Tana basin, the study estimated multivariate probit model to explain the factors that influence market outlet choice of smallholder vegetable producers. F-statistics was sued to verify the effect of market outlets on productivity and income. The results show that those households choosing both farm gate and local market simultaneously are found at better level of productivity and income. Multivariate probit results show that buyers visit and age of household head simultaneously determined all market outlets decision of producers. Those households visited by buyers at farm or village were found more likely to choose farm gate and roadside market outlets and less likely to sell the produce at market place. The implication is that as far as smallholder producers had access to alternative market outlets, they would earn better income by choosing appropriate combination of market outlets. Interventions that improve access to all market outlets could improve income and boost production of vegetables.
\end{abstract}

Keywords: Lake Tana basin, Market outlet, Multivariate probit, Smallholder farmers, Vegetable JEL: D81, Q12, Q13

\section{INTRODUCTION}

Vegetable crops are important sources of vitamins, minerals and proteins especially for Ethiopians where malnutrition is a problem because of heavy consumption of cereals such as teff, maize and wheat. Ethiopia has favorable agro-climatic conditions for the production of a number of vegetable crops. However, production and consumption of vegetables in the country is very low. For example, Tsegaye, Ahmed and Dilnesaw (2009) indicated that vegetable and fruit consumption is very low in Ethiopia and the country can be considered as Vitamin A Deficiency endemic. Production of vegetables relative to national crop production is also very low. In $2015 / 16$ main (Meher) production season, vegetable crops took up about 1.44 percent of the area under all crops at national level, and the production estimate of the same crop is about 2.18 percent of the total national peasant crop production of the season (CSA, 2016). Smallholder farmers contribute $95 \%$ of the fresh vegetable supplies to the domestic urban and regional export markets (EHDA, 2011). One of the causes for low production of vegetables is that most small scale vegetable growers are constrained with marketing problems such as low bargaining power due to lack of alternative market outlets, low price for the produce specially during harvesting season, poor infrastructure, poor product handling and storage facilities, and lack of market information (Bezabih and Hadera, 2007; Moti, 2007; Nigatu et al., 2010). Though the study area, Lake Tana basin is one of the most potential vegetable production areas in Ethiopia (EHDA, 2011), the remoteness of the area from the central market, Addis Ababa, and the existing poor road and communication infrastructure may exacerbate smallholders' vegetable marketing problems. Selecting the existing appropriate market outlets is also a challenge because of various factors that affect producers to select such relevant outlets. A number of studies on choice of market outlets have been carried out in the country. Bezabih et al. (2015), Abebe, Bihon and Gebremedhin (2011) and Moti (2007) revealed that institutional, socio-economic and technical factors influence market outlet choice decisions by farmers. However, no literature have found in the country that attempted to verify the effect of market outlet choice on either productivity or income of producer households. In addition, only few of the literature assume that market outlet choices are interdependent and require a model which can account correlation among market outlets like 
multivariate probit model. Hence, the study was aimed to verify the effect of market outlet choices on productivity and income of farmers. In addition, the study intended to identify the determinants of smallholder vegetable producers' decision to choose market outlets in Lake Tana basin. It informs concerned actors on specific interventions needed to maximize benefit from vegetable production.

\section{DATA AND METHODS}

\section{Description of the study area}

This study is conducted in three districts namely Takusa, Libo Kemkem and South Achefer where most parts of their areas lie in Lake Tana basin, Ethiopia. The geographical location of the Lake Tana basin extends from $10.95^{\circ} \mathrm{N}$ to $12.78^{\circ} \mathrm{N}$ latitudes and from $36.98^{\circ} \mathrm{E}$ to $38.25^{\circ}$ E longitudes. It is found in North-west part of Ethiopia, Blue Nile Basin. The majority of the populations are dependent on rain-fed agriculture. The majority of the land area, $51.3 \%$ of the Lake Tana Basin is used for agriculture, $29 \%$ is agro pastoral area, and $20 \%$ of the basin is covered by the lake water (Setegn, Srinivasan and Dargahi, 2008). The major crops produced in the basin are teff, wheat, millet, maize, chickpea, and barley while the common cash crops are onion, tomato, garlic, pepper and potato.

\section{Data sources and sampling procedure}

Combinations of quantitative and qualitative data from both secondary and primary sources were used for this study. Multi-stage sampling techniques were employed to select respondents from vegetable producing farmers. At the first stage, among fourteen districts located in the basin, three districts namely Takusa, Libo Kemkem and South Achefer were selected randomly to undertake formal survey on vegetable farming households. At the second stage, four peasant administrations (PAs) reside in the basin from each of the three districts were selected randomly. Lastly, depending on the number of vegetable producing households in selected PAs, about 385 vegetable producing households were randomly drawn (Table 1). Sample size for producer farmers was determined following Cochran (1963) assuming a large population and maximum variability in the proportion of the attributes, and with a desired $95 \%$ confidence level and $\pm 5 \%$ precision, the resulting sample size

$N=\frac{Z^{2} p q}{e^{2}}=\frac{(1.96)^{2}(.5)(.5)}{(.05)^{2}}=385$

Where: $N$ is the sample size, $Z^{2}$ is the abscissa of the normal curve that cuts off an area $\alpha$ at the tails (1- $\alpha$ equals the desired confidence level, 95\%), e is the desired level of precision, $\mathrm{p}$ is the estimated proportion of an attribute that is present in the population, and $\mathrm{p}$ is $1-\mathrm{p}$.

\section{Methods of data analysis}

Descriptive statistics specifically F-statistics and econometric analysis were used to analyze the effect of market outlet choice on productivity and income, and the determinants of market outlet choice. Productivity was addressed by dividing weighted output of six vegetable crops namely onion, tomato, garlic, potato, cabbage and pepper by total land allocated for these vegetables. The weighted average of the vegetable crops produced on the $\mathrm{i}^{\text {th }}$ farm, $\mathrm{Y}_{\mathrm{i}}$ is defined by (Sharma et al, 1999).

$Y_{i}=\frac{\sum_{r=1}^{S} P_{r i} Q_{r i}}{\sum_{i=1}^{n} \overline{\left(P_{l} / n\right)}}$

Where: $S$ denotes the number of different types of vegetable crops, $P_{r i}$ denotes the price received per $\mathrm{kg}$ by the $\mathrm{i}^{\text {th }}$ farm for vegetable crop type $r, Q_{r i}$ denotes the quantity of vegetable crop type $\mathrm{r}$ in $\mathrm{kg}$ for the $\mathrm{i}^{\text {th }}$ farm,

$\bar{P}=\sum P_{r i} * \frac{Q_{r i}}{Q_{i}} ; Q_{i}=\sum Q_{r i}$

and $\mathrm{n}$ denotes the number of farms in the sample

Gross income was calculated by taking the quantity of vegetables sold to the market, and transport cost was deducted from it to obtain net income collected from vegetable crop sales.

Decision on marketing outlet selection is a discrete choice from among alternative outlets available to producers. Because only the farmer's choice on a particular market outlet type is observed, the following latent structure univariate probit model for choice of each market outlet type can be specified (Maddala, 1983; Long, 1997; Greene, 2012).

$y_{i}^{*}=\boldsymbol{X} \boldsymbol{\beta}+u_{i}$

$y_{i}=\left\{1\right.$ if $y_{i}^{*}=\boldsymbol{X} \boldsymbol{\beta}+u_{i}>0 ; 0$ if $y_{i}^{*} \leq 0$

Where: $y_{i} *$ is the binary latent variable for outlet choice (observed if $y_{i}^{*}>0,0$ otherwise); and $\boldsymbol{X}$ is a vector of household-specific, institutional and socioeconomic factors determining market outlet choice. However, producers might select one or more market outlets simultaneously depending on the expected benefits and risks associated with each market outlets. The potential for simultaneous correlation across different market outlets suggests that a model addressing correlated choices is appropriate. In the presence of correlation among unobserved factors across choices, the simple probit or logit model will produce biased estimates of choice probabilities as well as incorrect standard error for $\beta_{\mathrm{j}}$ and inferences based on those for determining critical factors determining choices will lead to inconsistent results (Greene, 2008). Multivariate probit modeling techniques are appropriate for correcting such biases generated from correlation across choices (Train, 2003; Greene, 2008) because they allow for possible simultaneous correlation across alternative choices. Hence, this study adopted multivariate probit econometric technique to simultaneously model the influence of the set of independent variables on each of the different marketing outlet choice decisions, while allowing the unobserved (error terms) to be freely correlated (Mokhtarian and Tang, 2011; Arinloye et al., 2012, 2015).

Multivariate probit estimates M-equation probit models, by the method of maximum simulated likelihood (Cappellari and Jenkins, 2003). The variancecovariance matrix of the cross-equation error terms has values of 1 on the leading diagonal, and the off-diagonal 
elements are correlations to be estimated $\left(\rho_{j k}=\rho_{k j}\right)$, and $\rho_{j k}=1$ for $\mathrm{j}=\mathrm{k}$, for all $\left.\mathrm{j}, \mathrm{k}=1, \ldots, \mathrm{M}\right)$. In this study, the marketing outlet decision is considered as a system of a multiple choice equation respective to each type of marketing channel (Eq. 4).

Farmgate $_{i}^{*}=\boldsymbol{X}_{\mathbf{1}}^{\prime} \boldsymbol{\beta}_{\mathbf{1}}+\varepsilon_{1 i}$

Roadside $_{i}^{*}=\boldsymbol{X}_{\mathbf{2}}^{\prime} \boldsymbol{\beta}_{\mathbf{2}}+\varepsilon_{2 i}$

Marektplace $_{i}^{*}=\boldsymbol{X}_{3}^{\prime} \boldsymbol{\beta}_{3}+\varepsilon_{3 i}$

Where, $\mathrm{E}(\varepsilon \mid \mathbf{X})=0, \operatorname{Var}(\varepsilon \mid \mathbf{X})=1, \operatorname{Cov}(\varepsilon \mid \mathbf{X})=\rho$ and farmgate ${ }_{\mathrm{i}}$, roadside $_{\mathrm{i}}$ and marketplace $\mathrm{i}_{\mathrm{i}}$ are binary variables taking the value 1 when farmer $\mathrm{i}$ selects farm gate, roadside and market place, respectively and 0 otherwise; $\mathbf{X}_{\mathbf{1}}$ to $\mathbf{X}_{\mathbf{3}}$ are vectors of explanatory variables determining the respective outlet choice variables; $\beta$ 's are vectors of simulated maximum likelihood (SML) parameters to be estimated; $\varepsilon_{1}$ to $\varepsilon_{3}$ are correlated error terms in a seemingly unrelated multivariate probit model; and $\rho$ 's are tetrachoric correlations between endogenous variables. Possible explanatory variables and associated hypothesis are presented in Table 2.

Table 1: Sample distribution in districts, PAs and households

\begin{tabular}{llllr}
\hline Districts & $\begin{array}{l}\text { Peasant } \\
\text { administrations }\end{array}$ & $\begin{array}{l}\text { No of vegetable producer } \\
\text { households }\end{array}$ & Sample proportion & Sample size \\
\hline Takusa & Chankie & 1016 & 8.4 & 32 \\
& Mekonta & 636 & 5.2 & 20 \\
& Achera & 1085 & 8.9 & 34 \\
& Chemera & 942 & 7.8 & 30 \\
& District Total & 3679 & 30 & 116 \\
Libo Kemekem & Angot & 1110 & 9 & 35 \\
& Shina & 1098 & 9 & 35 \\
& Shamo & 1033 & 8.5 & 33 \\
& Agid & 1040 & 8.6 & 33 \\
& District Total & 4281 & 35.3 & 136 \\
South Achefer & Lalibela & 939 & 7.7 & 30 \\
& Ahuri & 1039 & 8.6 & 33 \\
& Abchikli & 1097 & 9 & 35 \\
& Kat & 1107 & 9 & 35 \\
& District Total & 4182 & 34.4 & 133 \\
Grand Total & & 12142 & 100 & 385 \\
\hline
\end{tabular}

Source: Each Districts Office of Agriculture and Rural Development (2017)

Table 2: Summary of explanatory variables and working hypothesis

\begin{tabular}{|c|c|c|c|c|}
\hline \multirow[t]{2}{*}{ Variables } & \multirow[t]{2}{*}{ Measurement } & \multicolumn{3}{|c|}{ Expected effect on market outlets } \\
\hline & & $\begin{array}{l}\text { Farm } \\
\text { gate }\end{array}$ & Roadside & $\begin{array}{l}\text { Market } \\
\text { place }\end{array}$ \\
\hline Age of household head & Continuous (No of years) & + & + & - \\
\hline Gender of household head & Dummy ( 1 for female, 0 otherwise) & - & - & + \\
\hline $\begin{array}{l}\text { Education level of household } \\
\text { head }\end{array}$ & Dummy (1 literate, 0 otherwise) & + & + & - \\
\hline Household size & Continuous (no of person) & - & - & + \\
\hline Vegetables farming experience & Continuous (in years) & + & + & - \\
\hline Livestock holding & Continuous (in TLU) & + & + & - \\
\hline Quantity of output sold & Continuous (quintals) & + & + & - \\
\hline Access to market information & Dummy ( 1 has access, 0 otherwise. & + & + & - \\
\hline Credit service & Dummy ( 1 has got credit, 0 otherwise) & - & - & + \\
\hline Distance to all-weather road & $\begin{array}{l}\text { Continuous (kilometer from home to } \\
\text { road) }\end{array}$ & + & + & - \\
\hline Crop diversification & Number of vegetable crops & - & + & + \\
\hline Buyers visit & $\begin{array}{l}\text { Dummy (1 visited by buyers, } 0 \\
\text { otherwise) }\end{array}$ & + & + & - \\
\hline
\end{tabular}




\section{RESULTS AND DISCUSSION}

\section{Demographic and socio-economic characteristics}

Vegetable producer sample households comprised of 91.4 percent male headed and 8.6 percent female headed households. The average age of the household heads was 42.6 years with a maximum of 70 and minimum of 22 years, indicating that most of the households were in the active age groups. The mean household size of the sample households was 5.9 a little bit higher than the national rural household size of 5.1 and Amhara region household size of 4.6 (CSA and WB, 2013). About 30 percent of the total sample household heads could not read and write, and 40 percent of them could only read and write. Sample household heads mean vegetable farming experience was 6.7 years. As indicated in Table 3, sample households average livestock holdings measured in Tropical Livestock Unit (TLU) was 5.8. The maximum holding was 18.2 TLU and the minimum was 0.07 TLU. Based on the survey result, households had allocated on average 0.70 hectares of land for vegetable, ranging from 0.125 to 2 hectares during the survey year (2017). On average a household produced about 33 quintals of vegetables during the survey year. Average gross income (excluding transport cost) of sample households obtained from vegetable production during the survey year was about 19535 Birr.

Market information, buyers visit, and road distance are considered as market access variables in the study. The sample households have different access to market information. On average, 70 percent of the sample households got at least price information from any source before they decided to deliver the produce to market. Another variable taken as a proxy for market access is buyers visit to villages which could be an evidence of the presence of alternative buyers around the rural areas. As indicated in the Table 3, about 36 percent of sample households were visited by buyers at village level. This could increase confidence to farmers related to market risk which in turn motivate farmers to increase marketable perishable crop production. The distance from farmers home to the nearest all weather road is also an alternative measure for market access. This variable measures the road access. Once the producers reach to the road, they can use vehicle or cart to easily transport the produce to market or they can sell their produce at road side. The result of the survey indicated that the average distance to the nearest all weather road was about 5 kilometers with the standard deviation of 3.12. The above market access variables indicated that farmers are required to exert considerable effort to take the produce to the road and market.

\section{Market outlet choice pattern of sample households}

The alternative market outlets available to vegetable producers in the study area include farm gate, roadside, market place and home. About 21.3 percent of vegetable producer households exploited farm gate as one of their alternative market outlets. Relatively small number of vegetable producers $(17.7 \%)$ selected roadside as an alternative market outlet (Table 4), may be due to inaccessibility of road. Market place was the main market outlet where 95.8 percent of sample vegetable producers were participated. It can be the district town market or market within the local peasant admi nistrative areas where any quantity of vegetable produce can be supplied. Very few farmers $(2.3 \%)$ were also able to sell their vegetable produce at home. Vegetable producers were also found to choose one or more market outlets simultaneously. As shown in Table 4 about 37 percent of sample households sold their produce through only one market outlet. About 17 and 9 percent of households used a combination of 2 and 3 market outlets jointly, respectively.

\section{Effect of outlet choice on productivity and income}

Smallholder farmers are used to sell their produce for one or more combination of market outlets depending on their objectives and availability of market outlets. One of their objectives might be earning higher income. This study was expected to find variation in income and productivity of vegetable producers choosing different market outlets. Hence, income and productivity of sample households under different market outlet choices were compared. About eight combinations of market outlets were found to be chosen by sample households, but some combinations were used by only few numbers of households. For example, two households chose all four outlets; farm gate, roadside, local market and home outlet, and six households used both farm gate and roadside. Hence, including very few observations for some combinations for statistical test may not be reliable. So for testing the effect of market outlets on productivity and income using F-test, roadside and home outlets were considered as similar with farm gate outlet. The justification is that significant variation among market outlets is expected on their transportation cost. Transportation cost at home and roadside outlet might be as low as farm gate transport cost compared with local market outlet. Thus, three combinations of market outlets i.e. farm gate, local market and combination of farm gate and local market were taken in to consideration. The result of F-test shown in Table 5 confirmed that the mean value of both yield and income of households significantly varied among these market outlets. Those households choosing both farm gate and local market outlets are found at higher level of yield and income followed by only farm gate sellers. The result indicates that better access to alternative market outlets could improve vegetable productivity and income of smallholder farmers.

\section{Determinants of vegetable market outlet choice}

Because home market outlet was hardly selected by households, only farm gate, roadside and market place outlets were considered in the econometric model. The result of the multivariate probit econometric regression is presented in Table 6. As presented in the regression output, the Likelihood ratio test is significant at 1 percent implying that the null hypotheses of all the rho values $\left(\rho_{12}=\rho_{13}=\rho_{23}=0\right)$ are jointly equal to zero or all the three market outlet choices are independently determined is rejected. The chi $^{2}$ test reported in Table 6 verifies that separate estimation of market outlet choices is biased and the decisions to choose the three market outlets are interdependent household decisions. Individual rho values 
indicate the degree of correlation between each pair of the dependent variables. The result of the model showed that the correlation between the choice for market place and farm gate $\left(\rho_{21}\right)$ and correlation between the choice for market place and roadside $\left(\rho_{23}\right)$ are both negative and statistically significant at less than $1 \%$ significant level. This finding indicates that farmers selling to the market place are less likely to sell to roadside and farm gate. Likewise, the correlation between farm gate and roadside sell $\left(\rho_{32}\right)$ is positive and significant, leading to the conclusion that those selling their vegetables at farm gate are more likely to participate in roadside sale.

The model also showed that the probability of selling vegetables to farm gate and roadside were 21.3 and 19.2 percent, relatively very low as compared to the market place outlet which was 95.5 percent. This may be due to less accessibility of farm gate and roadside sales for vegetable producers in the study area. The probability of vegetable producers to select all market outlets jointly was 7.2 percent indicating that households were unlikely to succeed to choose the three market outlets at the same season.

The results in Table 6 also showed that two variables, buyers visit and age of household head, simultaneously determined all market outlets decision of producers. As shown in the model result, the variable, buyers visit influenced farm gate and roadside outlet positively, and market place outlet negatively showing that producers who were visited by buyers before harvest are more likely to sell at farm gate and roadside, and less likely to take the produce to market place. The implication is that access to farm gate and roadside outlets could reduce transaction cost and market risks associated with perishability of the produce. The second variable which jointly determined all market outlets was age of household head. Higher age was assumed to favor selling at farm gate compared to market place and roadside because market place sale needs more energy in transporting the produce to market areas. However, contrary to the hypothesis, old age drives producers to be reluctant to sell to farm gate and roadside, rather it increases the likelihood to choose market place in selling vegetables. The reason might be that aged farmers are more uncertain about crop price because of uneasy access to information technology. In addition, old aged farmers may establish long lasting clients or customer buyers which would make market place sale less risky. Xaba and Masuku (2013) also found that aged cabbage farmers are reluctant to adopt new market channels.

Table 3. Summary of descriptive statistics

\begin{tabular}{lllll}
\hline Variables & Mean & Std. Dev. & Minimum & Maximum \\
\hline Age of household head & 42.6 & 8.61 & 22 & 70 \\
Gender of household head & 0.086 & 0.28 & 0 & 1 \\
Education level of household head & 0.70 & 0.458 & 0 & 1 \\
Household size & 5.94 & 2.01 & 1 & 13 \\
Vegetables farming experience & 6.67 & 4.16 & 0 & 25 \\
Livestock holding (TLU) & 5.8 & 2.66 & 0.07 & 18.2 \\
Access to market information & 0.7 & 0.46 & 0 & 1 \\
Credit service & 0.3 & 0.46 & 0 & 21 \\
Distance to all-weather road (km) & 5.05 & 3.12 & 0.47 & 4 \\
Crop diversification & 2.76 & 1.06 & 1 & 1 \\
Buyers visit & 0.36 & 0.48 & 0 & .72 \\
Weighted output in quintal & 32.62 & 25.66 & .72 & 2 \\
Land in hectare & .70 & .469 & .125 & 134.46 \\
Total output per hectare & 48.75 & 24.12 & 2.88 & 11.80 \\
Log of net income in Birr & 9.88 & 0.889 & 5.84 & \\
\hline
\end{tabular}

Source: Author's computation from sample survey data (2017)

Table 4: Market outlets and household choices

\begin{tabular}{llll}
\hline Market outlet & $\begin{array}{l}\text { Number of users } \\
(\%)\end{array}$ & $\begin{array}{l}\text { Number of market } \\
\text { outlets }\end{array}$ & $\begin{array}{l}\text { Number of users } \\
(\%)\end{array}$ \\
\hline Farm gate & 21.3 & 1 & 73 \\
Local market & 95.8 & 2 & 17.4 \\
Road side & 17.7 & 3 & 9.1 \\
Home & 2.3 & 4 & 0.52 \\
\hline
\end{tabular}

Source: Author's computation from sample survey data (2017)

Table 5: Sample household's yield and income comparison by market outlets

\begin{tabular}{|c|c|c|c|c|}
\hline Variable & $\begin{array}{l}\text { Farm gate } \\
(n=16)\end{array}$ & $\begin{array}{l}\text { Market } \\
(n=271)\end{array}$ & Farm gate $\&$ market $(n=98)$ & $\mathrm{F}=$ test \\
\hline Yield (output/ha) mean & $\begin{array}{l}52.96 \\
(16.585)\end{array}$ & $\begin{array}{l}45.63 \\
(22.247)\end{array}$ & $\begin{array}{l}56.69 \\
(28.088)\end{array}$ & $8.12 * * *$ \\
\hline Log of net income in Birr (mean) & $\begin{array}{l}9.92 \\
(0.717)\end{array}$ & $\begin{array}{l}9.81 \\
(0.8495)\end{array}$ & $\begin{array}{l}10.05 \\
(0.999)\end{array}$ & $2.68 *$ \\
\hline
\end{tabular}

Note; Figures in parenthesis are standard deviation

Source: Author's computation from sample survey data (2017) 
Table 6: Results of multivariate probit model

\begin{tabular}{lllcccc}
\hline \multirow{2}{*}{ Variables } & Farm gate & \multicolumn{3}{c}{ Market place } & \multicolumn{2}{c}{ Roadside } \\
& Coefficient & Std.Err & Coefficient & Std.Err & Coefficient & Std.Err \\
\hline Age & $-0.0339^{* * *}$ & 0.0111 & $0.0438^{* *}$ & 0.0188 & $-0.0239^{* *}$ & 0.0097 \\
Sex & -0.3128 & 0.3911 & 1.7893 & 47.7660 & -0.3632 & 0.3396 \\
Education level & -0.2931 & 0.1979 & $-0.7054^{* *}$ & 0.3450 & -0.0786 & 0.1870 \\
Household size & 0.0531 & 0.0596 & 0.0777 & 0.1063 & 0.0256 & 0.0550 \\
Farming experience & -0.0212 & 0.0248 & -0.0341 & 0.0455 & -0.0275 & 0.0236 \\
Livestock holding (TLU) & $0.1188^{* * *}$ & 0.0383 & $-0.1335^{*}$ & 0.0732 & -0.0350 & 0.0366 \\
Credit & -0.2061 & 0.1937 & 0.5697 & 0.3584 & -0.1119 & 0.1807 \\
Diversification & $-0.2770^{* * *}$ & 0.0940 & $0.4887 * *$ & 0.2016 & -0.0169 & 0.0915 \\
Market information & $0.7866^{* * *}$ & 0.2351 & 0.0137 & 0.3604 & 0.1664 & 0.2040 \\
Buyers visit & $0.8902^{* * *}$ & 0.1698 & $-0.6526 * *$ & 0.3018 & $0.4148 * *$ & 0.1677 \\
Distance to all-weather road & $-0.0650^{* *}$ & 0.0301 & 0.1370 & 0.0851 & $-0.0689 * *$ & 0.0292 \\
Output & 0.0014 & 0.0041 & -0.0099 & 0.0069 & $0.0153 * * *$ & 0.0037 \\
\hline Predicted probability & 0.2128 & \multicolumn{7}{c}{0.9555} & 0.0716 & 0.1918 & \\
Joint probability (success) & & & 0.0013 & &
\end{tabular}

Observations 385

○21 $-.8992 * * *(.1238)$

○31 .6065***(.0711)

p32 $-.5177 * * *(.1300)$

Wald $\operatorname{chi}^{2}(33) \quad 344.44 * * *$

Likelihood ratio test $\left(\mathrm{H}_{0}: \operatorname{rho} 21=\operatorname{rho} 31=\operatorname{rho} 32=0\right): \operatorname{chi}^{2}(3)=72.59 * * *$

Note: $* * * * *$ and $*$ indicate the level of significance at 1,5 and 10 percent, respectively; Figures in parenthesis are standard error Source: Author's computation from sample survey data (2017)

Livestock holding influenced farm gate sale positively, and market place sale negatively, indicating that farmers with large livestock herd tend to prefer farm gate, than market place. The reason may be high opportunity cost of labor for market place outlet given that livestock herding consumes additional labor for crop producers. The result of the model also indicated that farmers producing diversified vegetable crops were negatively influenced to sell at farm gate and positively influenced to decide to sell at market place. The possible reason might be that farm gate buyers (wholesalers and assembles) require relatively large volume of produce, and diversified crop producers supply small quantity of each crop which is not suitable for farm gate buyers. Another reason could be that diversified producers supply different crops at different harvest time. This would increase the cost of searching farm gate buyers. Hence, involving in diversified crops could decrease the possibility to exploit farm gate outlet as an alternative.

As expected, the variable market information in the model was found positively and significantly determining the decision on farm gate sale. It means that those who were able to get market information are more likely to sell at farm gate. The information could reduce price uncertainty and increase negotiation power of farmers in their farm. Geoffrey (2015) indicated that those farmers getting price information are less likely to sell at urban market perhaps to avoid high transaction cost at distant market.

Distance to all-weather roads was expected to favor farm gate sale, because as the distance of farmers' farm gets far from road, they tend to decide to sell at farm gate. However, the result is in contrary to the expectation that it affects farm gate and roadside outlets negatively and significantly. It means that as the distance of the farm increases from all-weather road, producers were less likely to choose farm gate and roadside to sell their produce. The reason might be that farm gate buyers may not get comfortable to go into producers' field far from road due to high cost of transport or high risk associated with poor road. This leads to the conclusion that those producers far from all-weather road could not have market outlet access to choose. Similar result was found by Giacomo, Chittur and Bhavani (2014) that remote farm households (furthest from local markets) are more likely to travel to the market may be the consequence of farm gate buyers not being prepared to travel to remote areas for which they may have to incur higher proportional transaction costs

\section{CONCLUSIONS}

The result of F-statistics indicated that productivity and income of sample households varied under different market outlet choice. Those households who used both farm gate and local market outlets simultaneously are found at higher level of income and productivity. In addition, the result of the multivariate probit model showed that the decisions to choose the three market outlets are interdependent household decisions. Decision on farm gate and roadside outlets are positively correlated, and negatively correlated with market place outlet. Two variables, buyers visit and age of household head, simultaneously determined all market outlets decision of producers. Producers who were visited by buyers before harvest are more likely to use farm gate and roadside 
outlets, and less likely to take the produce to market place. Old age farmers preferred market place outlet than farm gate and roadside outlets perhaps because of lack of access to price information or they established long lasting clients. In addition, livestock holding and market information positively influenced farm gate outlet and diversification and distance to road affected farm gate outlet negatively. It means that as the distance of the farm increases from all-weather road, producers were more likely to transport their produce to market place due to inaccessibility of farm gate and roadside outlets. Improving access to various market outlets through the expansion of roads and communication infrastructure could ease marketing of perishable vegetables. Moreover, local governments at peasant administration or district level should try to bring experienced and younger farmers together under experience sharing forums to share their farm practice knowledge and techniques of accessing market information.

\section{Acknowledgements}

The authors would like to thank Ministry of Education for financial support for this research. Moreover, we thank the sample respondents, enumerators and district experts for their valuable response during data collection process.

\section{REFERENCES}

ABEBE, E., BIHON, K. and GEBREMEDHIN, Y. (2011). Determinants of vegetable channel selection in rural tigray, northern Ethiopia. International journal of research in commerce \& management, 2(9).

ARINLOYE, D-D. A. A., HAGELAAR, G., LINNEMANN, A. R., PASCUCCI, S., COULIBALY, O. and OMTA, O. S. F. W. (2012). Multi-governance choices by smallholder farmers in the pineapple supply chain in Benin: An application of transaction cost theory. African Journal of Business Management, 6(38):10320-10331. DOI: $10.5897 / A J B M 12.365$

ARINLOYE, D-D.A.A., STEFANO, P., ANITA, R.L., OUSMANE, N.C., GEOFFREY, H. and ONNO, S.W.F.O. (2015). Marketing Channel Selection by Smallholder Farmers. Journal of Food Products Marketing, 21(4):337-357. DOI: $\underline{10.1080 / 10454446.2013 .856052}$

BEZABIH, E. and HADERA, G. (2007). Constraints and opportunities of horticultural production and marketing in eastern Ethiopia. Drylands Coordination Group, report, 46. Grensen 9b. Norway.

BEZABIH, E., MENGISTU, K., JEFFREYSON, K.M. and JEMAL, Y. (2015). Factors Affecting Market Outlet Choice of Potato Producers in Eastern Hararghe Zone, Ethiopia. Journal of Economics and Sustainable Development, 6(15).

CAPPELLARI, L. and JENKINS, SP. (2003). Multivariate probit regression using simulated maximum likelihood. The Stata Journal, 3(3):278-94. DOI: https://doi.org/10.1177/1536867X0300300305

COCHRAN, W.G. (1963). Sampling Techniques, 2nd Ed., New York: John Wiley and Sons, Inc.
CSA (Central Statistical Agency) and the World Bank (2013). Ethiopia Rural Socioeconomic Survey (ERSS) Survey Report, Addis Ababa.

CSA (Central Statistical Agency) (2016). Agricultural Sample Survey (2015/16). Volume I Report on Area and production of major crops (private peasant holdings, meher season), Statistical Bulletin.

EHDA (Ethiopian Horticulture Development Agency) (2011). Exporting fruit and vegetable from Ethiopia. Assessment of development potentials and investment options in the export-oriented fruit and vegetable sector. Addis Ababa, Ethiopia.

GEOFFREY, S.K., HILLARY, B.K., JONAH, K.K. and TIMOTHY, O.O. (2015). Factors Influencing the Choice of Marketing Outlets among Small-Scale Pineapple Farmers in Kericho County, Kenya. International Journal of Regional Development, 2(2). DOI: 10.5296/ijrd.v2i2.6237

GIACOMO, Z., CHITTUR, S. S. and BHAVANI, S. (2014). Transaction Costs, Information Technologies, and the Choice of Marketplace among Farmers in Northern Ghana, The Journal of Development Studies, 50:9, 12261239. DOI: 10.1080/00220388.2014.903244

GREENE, W.H. (2008). Econometric Analysis. 6th ed. Upper Saddle River, NJ: Prentice Hall.

GREENE, W.H. (2012). Econometric analysis. Seventh edition. New Jersey: Pearson Hall.

LONG, J.S. (1997). Regression models for categorical and limited dependent variables (RMCLDV). Thousand Oaks CA: Sage Press.

MADDALA, G.S. (1983). Limited-dependent and qualitative variables in econometrics. Cambridge: Cambridge University Press.

MOKHTARIAN, P. and TANG, W. (2011). Trivariate Probit Models of Pre-purchase/Purchase Shopping Channel Choice: Clothing Purchases in Northern California. Institution of Transportation Studies. Research Report UCD-ITS-RR-11-15.

MOTI, J. (2007). Econometric Analysis of Horticultural Production and Marketing in Central and Eastern Ethiopia. PhD Dissertation. Wageningen University. The Netherlands.

NIGATU, A., HOEKSTRA, D., KAHSAY, B. and MOTI, J. (2010). Irrigated vegetable promotion and expansion: the case of Ada'a woreda, Oromiya Region, Ethiopia. IPMS Ethiopia.

SHARMA, K.R.P., LEUNG, P. and ZALESKI, H.M. (1999). Technical, allocative and economic efficiencies in swine production in Hawaii: A comparison of parametric and nonparametric approaches. Agricultural Economics, 20: 23-35. DOI: https://doi.org/10.1016/S01695150(98)00072-3

SETEGN, S.G., SRINIVASAN, R. and DARGAHI, B. (2008). Hydrological modeling in the Lake Tana Basin, Ethiopia using SWAT model. The Open HydrologyJournal, 2 2: 49-62. DOI: $10.2174 / 1874378100802010049$

TRAIN, K.E. (2003). Discrete Choice Methods with Simulation. Cambridge: Cambridge University Press.

TSEGAYE, D., AHMED, A. and DILNESAW, Z. (2009). Availability and consumption of fruits and vegetables in nine regions of Ethiopia with special emphasis to vitamin 
A deficiency. Ethiop .J. Health Dev., 23(3):216-222. DOI: http://dx.doi.org/10.4314/ejhd.v23i3.53242

XABA, B.G. and MASUKU, M.B. (2013). Factors Affecting the Choice of Marketing Channel by Vegetable Farmers in Swaziland. Sustainable Agriculture Research, 2(1). DOI: $\underline{10.5539 / \text { sar.v2n1p112 }}$ 